\title{
The Effect of Using the Integrative Approach on Academic Achievement and Self-efficacy of Students of the College of Education
}

\author{
Moder Sabah Abd \\ College of Education, English Department, The Islamic University in Najaf, Iraq
}

Received November 21, 2020; Revised December 31, 2020; Accepted January 28, 2021

\section{Cite This Paper in the following Citation Styles}

(a): [1] Moder Sabah Abd, "The Effect of Using the Integrative Approach on Academic Achievement and Self-efficacy of Students of the College of Education," Universal Journal of Educational Research, Vol. 9, No. 1, pp. 171 - 179, 2021. DOI: 10.13189/ujer.2021.090119.

(b): Moder Sabah Abd (2021). The Effect of Using the Integrative Approach on Academic Achievement and Self-efficacy of Students of the College of Education. Universal Journal of Educational Research, 9(1), 171 - 179. DOI: 10.13189/ujer.2021.090119.

Copyright $\bigcirc 2021$ by authors, all rights reserved. Authors agree that this article remains permanently open access under the terms of the Creative Commons Attribution License 4.0 International License

\begin{abstract}
This study is an attempt to identify "the effect of using the integrative approach strategy on academic achievement and self-efficacy of students of the College of Education". It also shows the best method that develops the learners' ability of acquiring knowledge and sciences from the researcher's point of view. Through the research, it seems that there is a remarkable weakness in academic achievement and self-efficacy among students of the College of Education in the subject of educational psychology. For achieving the goal of this study, it is hypothesized that there is no statistically significant difference at the level of $(0.05)$ between the average scores of the experimental group students who study the scientific subject using the integrative approach and the average scores of the control group students who study the same subject in the usual way in attaining the educational psychology subject and in academic self-efficacy. The present study aims to discover the effect of using the integrative approach or strategy on imparting writing skills to students of English department, College of Education in Islamic university in Najaf for the academic year 2018-2019 AD.
\end{abstract}

Keywords Integrative Approach, Types of Integration, Self-efficacy, Academic Achievement

\section{Introduction}

Specialists in educational affairs are looking for appropriate teaching strategies, methods and approaches to develop educational work, taking into account that providing an interactive environment seeks to develop and improve the capabilities of learners and make the learner focus on the educational process and in light of the information age and the huge knowledge. The educational process elements are teachers, curricula, and learners. So it is necessary for us to study the bonds that bind these elements to each other and show their impact on modern curricula, methods, approaches, and modern strategies in various educational stages. This is what was brought by a number of opinions and ideas that addressed this issue in developing the curriculum with its various elements and clarifying and highlighting the importance of this relationship among elements to provide service to the learner in order to become an active element in society and private life and remove these barriers between knowledge. Correlation is important among the elements of life that reflect the educational performance side, so the search for methods and strategies that achieve this important requirement should correspond with these changes occurring in the educational environment of all stages.

(Al-Saadi, 2013: 21). 


\section{The Integrative Approach}

Many interdisciplinary units of expression can be called integration, such as: Interdisciplinary Studies and Units, Transdisciplinary Studies and Occasional Sciences, Multidisciplinary, Sequenced and Sequential Sciences, Connected and Inclusion, Thematic Units, Unified Approaches, Networked and Concept Networks, Thread and Spider Studies.

(Jasim, 2001: 9).

Al-Haddabiu Al-Jaji, (2008: 106) defined it as the approach that presents its concepts and vocabulary so that the unit of thinking between the different subjects increases the subject of the study clearly, so that the learner can perceive the overall picture of the topic and thus employ it to reach the unity of knowledge.

\subsection{Types of Integration}

There are two kinds of integration (Horizontal and Vertical)

A. Horizontal integration: This is through finding the horizontal relationship between the different areas that make up the curriculum, whereby attention is focused on topics with common elements between the related fields.

B. Vertical integration: or the so-called spiral construction, which simply means orientation towards the discipline of science in the curricula, adopting a pivotal concept and advancing it in depth and breadth and interfering in the branches of science and life whenever the student rises in a class

\subsection{The Principal of Integration}

A. The philosophical basis: Experience in modern educational thought is an integrated record that its parts cannot be separated from one another, as human life consists of a set of integrated experiences linked together to form a harmonious fabric, which is life.

B. The social basis: the nature of humanity and the situations of ordinary life do not set distinct boundaries for the process of acquiring experiences from a specific region. They try together to collect experiences in an integrated whole, due to the integration of society, harmony and unity among its various parts.

C. The cognitive basis: human knowledge is the outcome of a continuous interaction between a person and his environment, whose continuous changes lead to the emergence of new facts that serve as the rationale for other facts that will be discovered.

D. The psychological basis: the integration of educational experiences is an organizational process that occurs in the mind and thinking of the learner. Therefore, the organizational activity expresses itself continuously in the situations that the learner encounters and thus the learner becomes a mental trend. (Al-Jafri, 2010: 44)

\subsection{The Importance of Integrative Approach in Teaching and Learning}

The integrative approach in the teaching process is more realistic and is related to the life problems that students face in their lives, as the problems students face in their lives often require solving the most style and type of knowledge that the student learns, and that the approach's connection to life and the environment in which he lives motivates and increases his motivation to learning.

Teaching in an integrative approach helps to get rid of the repetition process that characterizes the curricula of separate subjects, which saves time for both the teacher and the student, does not arouse boredom for them, is more economical in effort and money, and knowledge is not part and can only be acquired through an integrated curriculum in it the detective and overlapping, and also integrated in the impact and the result.

The integrative approach in teaching takes into account the characteristics of students' psychological and educational growth, in terms of taking into account their tendencies, interests and preparations in what is provided to them in terms of knowledge, experiences and integrated information, which creates the tendency and motivation to study this information, that is, this approach takes the students' tendencies as an important basis from the foundations. Examining the problems and topics that they want to study, and the aspects of activity related to them prompt students to do their best to collect the information necessary to solve those problems, or to study these topics, so that learning is more beneficial and has a lasting impact because, it is learning based on their desire and in line with their preferences.

Employing the integrative approach helps to develop the teacher professionally and scientifically, as he finds himself in constant need to develop himself and diversify his information, in order to match the complex and diverse information he provides to his students.

It is possible to demonstrate the importance of the integrative approach, which is defined as a system that emphasizes the study of academic subjects as a continuous study and is organized by a psychological organization more than a traditional one and does not neglect the social benefit that students gain from what they study (El-Sherbiny and Al-Tantawi, 2011: 255). The integrative approach is important, including:

1. Helping students to read and understand consciously.

2. Spreading awareness among students to develop their capabilities.

3. Graduating workers in different professions. 
4. Answering students' questions about many things they want and are important to them.

5. Connecting students with knowledge.

6. Linking topics with life skills: such as the role of mathematics in life, the role of science in overcoming difficulties, and others.

7. Helping the student with social learning.

8. Helping the student to appreciate the role of the educational institution and society.

9. Finding a balance between students and society ( $\mathrm{Abu}$ Harb, 2011: 42).

\section{Academic Self-efficacy}

Pajares (1996:550) defined it as: the individual's belief and confidence about his own capabilities and information and the extent to which he can achieve a good level in academic tasks through exerting the required effort. Personality in his field of study (Al-Zghoul, 2003: 139).

\subsection{Social Cognitive Theory of the Concept of Self-efficacy}

Bandura's theory was known as Social Learning theory, but he renamed it Social Cognitive Theory in order to include the developments he had achieved in his theory, as many theorists believe that Bandura is a cognitive psychologist because of his focus on motivation factors and mechanisms. Self-regulation contributes to a person's behavior more than the influence of environmental factors alone (Bandura. 2001p1). Bandura's theory combines both behavioral theory in the concept of procedural conditioning that emphasizes the environment, reinforcement, and a cognitive theory (Pagares.2003.p55). And that social cognitive theory envisages that individuals have effective forces in their behaviors, meaning that they can regulate their environment, increasing the chances of the desired response occurring (Stipek.1988.p44). In his theory on the concept of self-efficacy, Bandura points out that the behavior of perseverance and initiative of the individual depend on the individual's judgments and expectations related to his behavioral skill, and his adequacy to successfully deal with the challenges of the environment and surrounding circumstances, and these factors in Bandura's view play a role important in psychological adjustment, disorder, and in determining the success of the individual in solving emotional problems. (Hamdi and Randa, 2011: 24) and (Pajares. 2005), citing (Al-Alwan and Randa, 2011) that self-efficacy shows its impact by helping to determine the amount of effort an individual will exert in a particular activity, the amount of perseverance in facing obstacles, and the amount of Toughness in facing difficult situations, the greater the individual's sense of self-efficacy, the greater the effort, perseverance, and toughness. Individuals with high self-efficacy deal with situations, problems, and activities with more sobriety (Alwan and Randa, 2011: 399), and self-efficacy mediates as seen (Harackiewicz 1995). (Referred to in (Al-Khafaji, 2013), the effects of hints of efficiency on internal motivation, and the internal tendency enhanced by satisfaction with the outcome in achieving the goal or the perception of competence, but in the event of dissatisfaction, or lack of awareness of competence, the next internal tendency is reduced (Al-Khafaji, 2013:21).

This theory also focuses on the importance of personal evaluation as a means of positive reinforcement, as achieving a personal goal, or reaching the level of personal achievement and the attendant level of self-satisfaction can work effectively as a reinforce, and the feeling of satisfaction to achieve the goal acts as a reward, which in turn increases Effort in the future (Stipek.1981.p43) In light of the above, the concept of self-efficacy is a major axis of social cognitive theory, which believes that the individual has the ability to control his behavior as a result of his beliefs. Personality, individuals have a system of self-beliefs (Self-Beliefs) that enables them to control their feelings and thoughts (Bandura.1986.p102) and accordingly, how the individual thinks, believes, and feels influences how he acts as these beliefs form. The essential step to control the individual's behavior, and works is to explain his accomplishments depending on his ability which makes him do his best to achieve success (Bandura.1997.p40).

\subsection{Sources of Self-efficacy}

Bandura emphasized that self-efficacy is strengthened through four sources of information:

A. Alternative experiences: It is the second source that individuals derive their personal efficiency and effectiveness. This happens when they watch others deal with threats and eventually succeed. Such experiences enable observers to expect that they will be able to achieve some improvement in performance if they continue increasing their efforts (Bandura.1977.p126).

B. Verbal persuasion: Al-Ahmadi (2015) mentions that the source of verbal persuasion indicates information that an individual gets verbally from others. This kind of persuasion represents a kind of motivation for performing a duty and it will influence the individual's behavior while attempting to achieve the duty in question. Verbal persuasion is considered as a source of support for an individual's self-efficiency. It should be linked to achievement because it is difficult to convince others in their competence when they have not achievements (Al-Ahmadi, 2005: 29).

C. Emotional arousal: Al-Khafaji (2013: 32) mentions that this source depends on the state of motivation available in additional situations to the state of 
emotional individuals. Emotional arousal appears in difficult situations in general, which require great effort. The amount of effort differs from one situation to another depending on the nature of the situation and the available information about the ability in terms of competence. The high emotional arousal usually weakens performance (Al-Khafaji, 2013: 32).

\section{Literature Review}

In Integrative Approach Abu-Dahroug's Study (2016) mentions that the individual learns through his first experience the meaning of success and a sense of control over the environment, meaning that personal achievement is an important source for the individual's sense of self-efficacy. (Al-Atoum et al., 2011: 120-121).

The effectiveness of a program based on an integrative approach in developing some writing skills among third-grade female students. The experimental approach is followed in this study, where she confined to one experimental sample to measure the effectiveness of the program before and after its implementation. The study also adopted the structural approach for building the program in question and the analytical approach for analyzing content of two Arabic language lessons. The study population consists of all female students of middle third grade in UNRWA schools. The study sample consists 31 students as an experimental group who were selected randomly. In order to achieve the study aims, the researcher has prepared a list of all writing skills depending on the analyzed contents of the Arabic language lessons. Then the researcher has constructed a test to measure writing skills. On the basis of the test, she has built her program in terms of the integrative approach. After verifying its validity and reliability statistically, the following has been found:

1. There are statistically significant differences between the average scores of the female students in the test of written expression skills before and afterwards in favor of the post.

2. The presence of statistically significant differences is between the average scores of female students in the pre and post dictation skills test in favor of the post.

The Al-Saghir's Study (2018) aimed at (building a computerized program in communication skills based on an integrative approach and testing its effectiveness in comprehension skills among tenth class students). To achieve the objectives of the study, the comprehension test was prepared after checking its validity and reliability, and the research sample was chosen intentionally. It consisted of (67) students from the tenth grade of basic students, and they were divided randomly into an experimental group consisting of (34) students and the control group consisting of (33) students. Four units of the communication skills research in the Arabic language were taught for the tenth grade of basic education using the computerized program, while the control group was studied in the traditional way. After processing the data statistically, the results showed an effect of using the computerized program based on the integrative approach in improving the comprehension skills of the tenth grade students in favor of the experimental group (Al-Saghir, 2018: 493).

In Self-Efficacy, Abid's (2016) Study identified the effect of the focused list strategy on developing academic self-efficacy among first intermediate students in biology. The researcher chose the experimental design with partial control for the experimental and control group with pre and posttest. The research sample size becomes (56) students divided into two groups. It was chosen randomly, where group (B) was formed to represent the experimental group that will be studied according to the focused list strategy, and group (A) to represent the control group that will be studied in the usual way. The researcher built the Academic Self-Efficiency Scale, which consists of (47) items distributed into four domains. The results of the study showed that there are statistically significant differences between the experimental and control groups in the variable of developing academic self-efficacy in favor of the experimental group.

Al Badayer's (2017) Study identified the effectiveness of the blog within scientific missions in learning and academic self-efficiency for intermediate second grade students in physics. The current research was limited to intermediate and high school students of the General Directorate of Education in Qadisiyah Governorate/ Afak District Education, for the academic year 2016-2017. The population of the study consists of six schools containing computer labs. The researcher adopted the experimental design with partial control for two equivalent groups, experimental and control, with a post-test for achievement and academic self-efficacy. According to this design, the study sample (Gharib Tous Intermediate School for Boys) was chosen randomly. It consists of 101 second intermediate grade students distributed into three classes, two divisions were chosen randomly to represent the experimental group and it included (30) students who studied the scientific subject using the electronic blog, and the other was the control group which included (30) students who studied the same subject in the usual way. The researcher has formulated 134 behavioral objectives for the lessons. The researcher prepared (18) teaching plans for the experimental group and likewise for the control group. With regard to the two research tools, (1) an achievement test consisting of (40) items of the multiple-choice type with four alternatives, and (2) a scale of academic self-efficacy consisting of (40) items were prepared. The psychometric properties were verified by using (Microsoft Excel 2010) and (SPSS 21) program. The results showed that there are statistically significant differences in favor of the experimental group in the 
achievement test. The magnitude of the differences is equal to the magnitude of the independent variable effect (electronic blog). The results also indicate that there are statistically significant differences in favor of the experimental group in the measure of academic self-efficacy. The magnitude of the differences is almost equal to the magnitude of the independent variable effect which has a considerable statistical value (0.856).

The two previous studies In Integrative Approach agreed with the current research in its use of the experimental method, where as Abu-Dahroug's study aimed at the effectiveness of a program based on the integrative approach in developing some writing skills among the third-grade students, while Al-Sagheer's study aimed to build a computerized program in comprehension skills for tenth grade female students. The two studies agreed in the type of the tools used in constructing the achievement test, whether for writing skills or comprehension, while the two studies differed in their samples. Abu-Dahroug's sample consisted of third grade students, while Al-Sagheer's sample consisted of tenth grade students. The current research took its sample from students of the College of Education in the Islamic University. The results of the two previous studies are almost the same. The current research may or may not agree with the two previous studies. This is what the researcher tries to do.

The two previous studies In Self-Efficacy agreed with the current research in adopting the experimental approach, where as Abid's (2016) study investigated the effect of the focused list strategy on developing academic self-efficacy among first-year intermediate students in biology, while Al-Badiri's (2016) study examined the effectiveness of the electronic blog within the scientific tasks in the achievement and academic self-efficacy of second-year intermediate students in physics. The two studies differed in the number of their tools and their variables; the Abid's study relied on the self-efficacy scale consisting of (47) items, while Al-Badiri's study is based on the achievement test and the aptitude scale consisting of (40) items. The two studies also differed in their samples, Abid's study sample consisted of 56 students from the first intermediate grade, while Al-Badiri's study sample included 60 students from the second intermediate grade.

\section{Research Procedures}

\subsection{Experimental Design}

Adopting the appropriate experimental design for the investigated phenomenon is essential to get answers to the research hypotheses and to contribute to the experimental control of the research. It serves as a work program for how to implement the experiment and control the circumstances and factors surrounding the studied phenomenon and its observation (Al-Fatlawi, 2014: 159). The design is illustrated in Table (1).

Table 1. Controlling factors

\begin{tabular}{|c|c|c|}
\hline Group & $\begin{array}{c}\text { Independent } \\
\text { variable }\end{array}$ & Post test \\
\hline Experimental & $\begin{array}{c}\text { Integrative } \\
\text { Approach Strategy }\end{array}$ & $\begin{array}{c}\text { Achievement }- \\
\text { self-efficacy }\end{array}$ \\
\hline Control & ----------- & \\
\hline
\end{tabular}

\subsection{The Research Participants and Sample}

The current research participants consisted of all first-grade students (190 students) / Department of English Language / College of Education - Islamic University / for the 2018-2019 academic years. The researcher chose, intentionally, the first-grade students the Department of English Language in the College of Education - the Islamic University as a population for his study. Among the 190 students, he chose his sample randomly. It consists of the group (A) (42 students) as an experimental group and the group (B) (40 students) as a control group. The former has been taught by using the integrative approach strategy and the latter has been taught by using the classical method; without exposing them to the independent variable.

The table below shows the arithmetic mean, standard deviation, and the calculated $\mathrm{T}$ value for the scores of the students of the two research groups (experimental and control) in the post-achievement test.

Table 2. Arithmetic deviation

\begin{tabular}{|c|c|c|c|c|c|}
\hline The group & $\begin{array}{c}\text { The } \\
\text { Number }\end{array}$ & $\begin{array}{c}\text { Arithmetic } \\
\text { average }\end{array}$ & $\begin{array}{c}\text { standard } \\
\text { deviation }\end{array}$ & $\begin{array}{c}\text { The computed t } \\
\text { value }\end{array}$ & $\begin{array}{c}\text { The tabular t } \\
\text { value }\end{array}$ \\
\hline Experimental & 42 & 44.69 & 6.52 & \multirow{2}{*}{ indication } & \multirow{2}{*}{ Function } \\
\hline Control & 40 & 29.22 & 9.27 & \\
\hline
\end{tabular}

Table 3. Self-Efficiency Scale

\begin{tabular}{|c|c|c|c|c|c|c|}
\hline The group & $\begin{array}{c}\text { The } \\
\text { Number }\end{array}$ & $\begin{array}{c}\text { Arithmetic } \\
\text { average }\end{array}$ & $\begin{array}{c}\text { standard } \\
\text { deviation }\end{array}$ & $\begin{array}{c}\text { The computed t } \\
\text { value }\end{array}$ & $\begin{array}{c}\text { The tabular t } \\
\text { value }\end{array}$ & \multirow{2}{*}{ indication } \\
\cline { 1 - 4 } Experimental & 42 & 21.5 & 12.76 & 3.49 & 1.98 \\
\hline Control & 40 & 12.6 & 10.08 & Function \\
\hline
\end{tabular}


The Table 3 shows the arithmetic mean, standard deviation, and the calculated $\mathrm{T}$ value for the scores of the students of the two research groups (experimental and control) in the Self-Efficiency Scale.

\subsection{Equalization of the Two Groups}

Before undertaking his experiment, the researcher worked to make the two research groups (control and experimental) equivalent in: the students' age, academic achievement rate, education and degree of intelligence, and he found that the two groups are equivalent in the studied variables.

\subsection{Research Requirements}

1. The researcher design his syllabus (items from the educational psychology) to teach the two groups of the research. The study period was the academic year (2018-2019) as whole. The syllabus has been modified and validated by a jury.

2. Behavioral objectives determination: The researcher has formulated a number of behavioral objectives in a manner that describes the learner's behavior and expects that the learner will be able to perform it. $\mathrm{He}$ formulated 278 cognitive behavioral objectives distributed on the six levels (remembering, understanding, application, analysis, synthesis, and evaluation). These levels are adopted in formulating the teaching plans of the two research groups and in building the items of the achievement test. The behavioral objectives have been presented to a group of experts in teaching methods to express their opinions on them and the extent to which they fulfill the content of the material and in light of their opinions and proposals that they have been modified.

3. Preparing teaching plans: The researcher designed a set of teaching plans for the two research groups (54 plans). These plans are divided into 27 plans for the experimental group and they are based on the strategy of successful intelligence. The other 27 plans have been designed for the control group according to the usual method. Samples of the teaching plans were presented to a jury to ensure their suitability for measuring the objectives formulated. In light of jury's instructions, the plans have been modified.

\subsection{Structuring of the Achievement Test}

1. In light of the subject matter and the behavioral objectives, the researcher prepared an achievement test of a multiple-choice type. The forty paragraphs of the test were presented to a group of experts and specialists in teaching methods to benefit from their opinions and

2. Observations about it. On the basis of the experts' instructions, the researcher made his modifications. The researcher adopted a percentage of $80 \%$ or more as a criterion for validity of paragraphs, thus achieving apparent validity. The content of the subject matter was analyzed into its basic elements and the behavioral objectives were identified. He developed a table of specifications and built an achievement test that are appropriate to the specification table and consistent with the specific behavioral objectives, all of which verify the validity of the content as Al-Zahir indicates that the use of the specification table is an indication of the validity of the test content (1999: 289). He also set instructions on how to answer, correct and statistically analyze all test items by applying the test to an exploratory sample. This sample is taken from a population far from the research sample. It consists of (50) male and female students from the University of Kufa / College of Education / Department of English Language. The aim behind the recent test is to know the extent of clarity of the test items and the students' ability to understand them. It helps also in determining the time required to answer the paragraphs and indicating if there is a kind of ambiguity in the test items. At the end of the test, it became clear that the instructions and test items are clear and the time required to answer was (45) minutes.

3. The statistical analysis of the test items was carried out by applying it to a sample of (190) male and female students from the University of Kufa / College of Education for the purpose of knowing the level of difficulty of the paragraphs and the parameters of their distinction and the effectiveness of their incorrect alternatives. The students' scores were arranged in descending order, and it was found that the difficulty factor of the paragraphs ranged between $(0.42-0.75)$. This rate is accepted because the acceptable range, as determined by the researchers, is between $(0,20-0,80)$. The distinction parameter ranged between $(0,30-0.64)$, which is within the acceptable range approved by specialists in measurement and evaluation; the acceptable range is $(0,20)$ or more (Allam, 2000: 268). In order to measure the stability of the achievement, the researcher used test equation of Koder Richardson 20 , which is an indicator of internal consistency, and the value of the stability factor was $(0.83)$. Studies indicate that the stability factor can be trusted if the stability factor reaches $(0.75)$ or more (Al-Zamili et al., 2009: 249).

4. Building the Self-Efficiency Scale: After reviewing the previous studies, the researcher prepared the Self-Efficiency Scale, as the number of its paragraphs reached (40) in its final form. The scale in question had been presented to a group of experts and specialists in educational and psychological sciences and teaching methods to benefit from their opinions and observations, and it was considered valid after 
making some amendments. The researcher adopted a percentage of $80 \%$ or more as a criterion for the validity of the paragraphs to verify the apparent reliability with giving special instructions. The scale paragraphs were analyzed statistically by applying it to a sample of (190) male and female students, and it became clear that the time required to answer is (44) minutes. After conducting the statistical analysis, it became clear that the level of difficulty ranges between (0.26-0.53). This value is acceptable, and the reliability factor was 0.89 , which is a good stability factor. The researcher used equation (Koder Richardson - 20) to measure the stability of the achievement test, which is an indicator of internal consistency, and the value of the reliability coefficient was (0.83). (Al-Zamili et al., 2009: 80)

Statistical methods: (T-test for two independent samples, Chi-square (Ca2), Keoder Richardson-20 equation to measure the stability of the achievement test).

Third: explanation of academic achievement results:

The results showed the superiority of the experimental group over the control group in the achievement test. The use of the integrative approach strategy had a significant impact in promoting student achievement, and the reason for this may be attributed to:

1. The integrative approach strategy opened enough room for students to rely on themselves to arrive at the answer. This made them motivated to work and made the educational psychology class more interesting.

2. The superiority of the experimental group students is due to the fact that they have receptivity and inclination to modern methods in the teaching process that pushes them to investigate aspects of the new strategy, through which they study the educational psychology subject, to a greater extent than the usual method they are familiar with.

Fourth: The results related to academic self-efficacy showed the superiority of the experimental group students who studied through the integrative approach strategy over the control group students who studied the same subject through the classical methods in the academic self-efficacy scale, and the researcher attributes this to the following reasons:

1. The use of the integrative approach strategy has made the students feel that they are independent from their teachers in the learning process. Feeling of independency and responsibility contributed to raising the students' self-confidence and self-esteem, and this helps to raise his academic self-efficacy, since self-efficacy is an individual's expectations or beliefs about what tasks can be done (Abdul, 2016, p.231).

2. The integrative approach strategy provided opportunities for dialogue and discussion among students through cooperating groups in accomplishing scientific tasks. The cooperation between students helps in developing the closest growth area, which leads to increased experiences and interaction between them and the teacher, and this also helps in raising their academic self-efficacy. The classical (prevailing) method relied for the most part on the teacher. This led to no significant increase in their self-efficacy, as the classical method does not work to increase students' self-confidence. The lack of interaction between students also affects, negatively, their expectations about what tasks they can perform and then their academic self-efficacy.

\section{Conclusions}

In light of the researcher's findings, the following can be concluded:

1. The use of the integrative approach strategy in teaching educational psychology can achieve the educational and behavioral objectives required for students at this stage in a better way than the classical methods. This approach provides students with a general idea of the topics that he will study, and it creates connection between what he will learn and its cognitive structure and the educational situation.

2. Teaching according to the strategy of the integrative approach has a greater impact than the classical method because it gives the learner an opportunity in the educational situation. This happens by arousing the learner's interest in the academic subject and placing him in an unfamiliar stance.

\section{Recommendations}

In light of the research results, the researcher recommends the following:

1. Adopting modern strategies to increase student achievement and develop capabilities, motivation and knowledge.

2. Getting benefit from general and behavioral objectives and educational activities in the education process, because they increases students' motivation to learn.

3. The necessity for teachers to focus on developing their students' academic self-efficacy by using appropriate strategies.

4. Not focusing only on raising student achievement because achievement is affected by several important factors, the most important of which is academic self-competence.

\section{Proposals}

To complement and develop the current research 
findings, the researcher proposes the following:

1. Studying the effect of using the integrative approach strategy on other variables, such as critical thinking, innovative thinking, visual thinking, and visual perception.

2. Studying the effectiveness of the integrative approach strategy in teaching other subjects and for different educational stages.

\section{REFERENCES}

[1] Abu Harb, Y. (2011). Tawajuhat fi Al-Manhaj Al-Tarbawii. Amman: Al-Falah Library for Publishing and Distribution.

[2] Abu-Hamada, S. (2013). 'Iithr Tawzif Al-Saburat Al-Dhakiyat fi Tadris Al-Jughrafiat Ealaa Tanmiat Al-Mafahim Al-Jughrafiat Wamaharat Aistikhdam Al-Kharayit ladaa Tullab Al-Safi Al-Tasie fi Muhafazat Ghaza. An Unpublished Master's Thesis, Al-Azhar University, College of Education, Gaza.

[3] Abu Dahrouj, Iman Nawwaf (2016) Faeiliat Barnamaj Qayim ealaa Al-Manhaa Al-Takamulii fi Tanmiat Bed Maharat Al-Kitabat Ladaa Talibat Al-Safi Al-Ththalith Al'asas Bighaza. An Unpublished Master's Thesis. Gaza: College of Education - Islamic University.

[4] Abu-Allam, S. (2010). Elim Al-Nafs Al-Tarbui. Amman: Dar Al Fikr.

[5] Al-Ahmadi, B. (2005). Ather Barnamaj Arshady Jamei fi Tanmiat Al-Kafa'at Al-Dhdhatiat Limuealamat Dhwyi Alaihtiajat Alkhasa. Unpublished Master Thesis. Basra: College of Education for Human Sciences, University of Basra.

[6] Al-Asadi, S. (2014). Falsifat Al-Tarbiat fi Al-Taelim Aljamieii Waleali. Amman: Safa House for Publishing and Distribution.

[7] Basem, S. (2001). "Nazariat Al-Manhaj Ashraq Mustaqbal Al-Eulum fi Al-Dirasat Al-Biyiyat Nahw Manhaj Takamuli," Journal of the College of Education. 254, 1.

[8] Al-Budairi, H. (2017). Faeiliat Al-Mudawanat Al-'iiliktruniat Dimn Muhimmat Eilmiat fi Al-Tahsil Walkaffa'at Al-Dhdhatiat Al-Akadymiat Ladaa Tullab Al-Safi Al-Ththani Al-Mutawasit fi Madat Al-Fayzya'. Unpublished Thesis. Al-Qadisiyah: College of Education, University of Al-Qadisiyah.

[9] Jassim, S. (2001). "Nazariat Al-Munahaj Aistishraf Mustaqbal Al-Eulum fi Al-Dirasat Al-Biyiyat Nahw Manhaj Takamuli", Journal of the College of Education, Egypt (25), 1 ,

[10] Al-Jalali, L. (2011). Al-Tahsil Al-Dirasiu. Dar Al Masirah for Publishing and Distribution: Amman.

[11] Al-Haddabi, D. and Al-Jaji, R. (2009). Faealiat Al-Munahaj Al-Takamulii fi Tanmiat Maharat Al-Tafkir Al-Eilmii Ladaa Talibat Asafi Al-Ththani Lithanwy Al-Eilmii, Sixth Arab Scientific Conference for the Care of Gifted and Outstanding Students - Nurturing the Gifted is an imperative for a better Arab future, Volume 1, Amman.
[12] Al-Khafaji, M. (2013). 'Al-Kafa'at Al-Dhdhatiat Al-Madrakat Waealaqatuha Bihali Al-Mushkilat Ladaa Al-Murashidin Al-Turbuiiyn," Unpublished Thesis. Baghdad: College of Education, Al-Mustansiriya University.

[13] Al-Caliph, H. (2014). Al-Manahaj Al-Madrasiu Al-Mueasir. Riyadh: Al-Rashed Library.

[14] Al-Khayyat, A. (2001). Ara' Muelimin Wamuajihi Al-Mawadi Al-Aijtimaeiat Hawl Aistikhdam Al-'uslub Al-Takamulii fi Bina' wa Tadris Manhaj Al-Mawadi Al-Aijtimaeiat Lilsafin Al-'awal Walththani fi Al-Marhalat Al-Ththanawiat Bidawlat Al-Kuayt. The Educational Journal. Kuwait University. 16, (61).

[15] Al-Khayyat, A. and al-Huli, A. (2003). Dirasat Tahlilat Limazahir Al-Takamul Bayn Mafahim Munhaj Madat Al-Aijtimaeiat wa Muhtawaa Manahij Mawadi Al-Safi Al-'awal Al-Mutawasit fi Dawlat Al-Kuwayt. Journal of the College of Education. The United Arab Emirates University Eighteenth Year, 20.

[16] Al-Zamili, A. et al. (2009). Mafahim wa Tatbiqat fi Al-Qias wa AL-Taqwim Al-Tarbawi. Kuwait: Al Falah Library for Publishing.

[17] Zaitoun, K. (2004). Tadris Al-Eulum Lilfahim Ruyat Binayiyat. Cairo: The World of Writers.

[18] El-Sherbiny, F. and El-Tanawi, E. (2011). Madakhil Tarbawiat fi Tatwir Al-Manahij Al-Taelimia. Cairo: The Egyptian Anglo Library.

[19] Al-Saadi, B. (2013). Faeiliat Aistikhdam Wahdat Qayimat ealaa Al-Manahaj Al-Takamulii fi Tanmiat Maharat Al-Lughat Al-iinkliziat Litalibat Al-Safi Al-Thalith Al-Thanwi. Unpublished PhD Thesis, Umm Al-Qura University, Saudi Arabia.

[20] Al-Safi, A., Qara, S. and Dabur, A. (2010). Taelim Al-'atfal fi Easr Al-Aiqtisad Al-Maerifii. Amman: House of Culture for Printing and Publishing.

[21] Al-Saghir, K. (2018). Bina' Barnamaj Muhwsib fi Maharat Al-Aitisal Qayim ealaa Al-Manhaa Al-Takamulii Waikhtaba Faeiliatuh fi Maharat Al-Fahimi Ladaa Talibat Al-Safi Al-Eashir Al-'asasii fi Al-'urduni. Journal of Studies in Educational and Psychological Sciences, 4, 43, Amman, Jordan.

[22] Al-Zahir, Z. Et al. (1999). Mabadi Al-Qias Waltaqwim Al-Tarbuii. Amman: House of Culture for Publication and Distribution.

[23] Abd, I. (2016). "'Athr 'iistratijiat Al-Qawayim Al-Markazat fi Tanmiat Al-Kafa'at Al-Dhdhatiat Al-Dirasiat Ladaa Tullab Al-Safi Al-'awal Al-Mutawasit fi Mabadi Eilm Al-'ahya'”. Al-Dean's Journal. Shiite Endowment Office, Iraq. $5,18$.

[24] Al-Atoum, A., Al-Jarrah, A. and Abu Ghazal. M. (2011). Eilm Al-Nafs Al-Tarbuiu Al-Nazariat Waltatbiq. Amman: Dar Al-Masirah for Publishing, Distribution and Printing.

[25] Iraq, Ministry of Higher Education and Scientific Research (1987). Al-Mutamar Al-Thalith Liltaelim Al-Eali Lilfatrat min 21-23-27, C1, boycotted the Faculties of Educational Sciences, Baghdad.

[26] Alwan, A. and Al-Mahasna, R. (2011). "Al-Kafa'at 
Al-Dhatiat fi Al-Qira'at Waealaqatiha Biastikhdam Aistiratijiat Al-Qira'at Ladaa Eayinat min Telbat AlJamieat Al-Hashimia". Jordan Journal of Educational Sciences. 7, (4).

[27] Ali, M. (2009) Al-Tarbiat Al-Eamaliat Watadris Al-Eulum. Amman: Dar Al Masirah for Publishing, Distribution and Printing.

[28] Al-Fattli, H. (2013). 'ususu Al-Bahth Al-Eilmiu fi Al-Eulum Al-Tarbawiat Walnafsiat Mafahimah Waeanasiruh Wamanahijuh. Amman: Dar Al-Safa for Publishing and Distribution.

[29] Ferjani, N. (2005). The Arab Strategy for the Development of Higher Education Organization for Education. Tunisia:
Culture and Science.

[30] The Arabic Language Academy (2004) Al-iistratijiat Al-Earabiat Litatwir Al-Taelim Al-Eali Al-Munazamat Liltarbiat Walthaqafat Waleulum, Al Shorouk International Press.

[31] Al-Mousawi, M. (2012). Al-Maejam Al-Wasit, Iraqi Scientific Center. Beirut: Insights Library House.

[32] Yaqoub, N. (2012). Al-Kafa'at Al-Dhdhatiat Al-Madrakat Waealaqatuha Bidafieiat Al-'iinjaz Waltahsil Al-Akadymy Ladaa Tullab Kliyat Jamieat Al-Malik Khalid. Journal of Educational and Psychological Sciences, (13), (3). 